\title{
IMPLEMENTASI KEBIJAKAN PROGRAM KELUARGA HARAPAN (PKH) DI KABUPATEN ENREKANG
}

\author{
Fajrin Mahmud ${ }^{1}$, Nuryanti Mustari ${ }^{2}$, Nasrulhaq $^{3}$ \\ ${ }^{1}$ Mahasiswa Program Studi Ilmu Administrasi Negara Fisip Unismuh \\ ${ }^{2}$ Dosen Program Studi Ilmu Administrasi Negara Fisip Unismuh \\ ${ }^{3}$ Dosen Program Studi Ilmu Administrasi Negara Fisip Unismuh
}

\begin{abstract}
This study aimed to know the Implementation Policy of the Family Hope Program;Program Keluarga Harapan (PKH) and find out the supporting and inhibiting factors of the Hope Family Program in Enrekang Regency. This study used descriptive qualitative research, one of the procedures that produced descriptive data in the form of words both in writing and verbally from someone and observed behavior. Data collection techniques were observation, interviews with a number of informants. The results showed that the Implementation policy of the Hope Family Program in Enrekang District had not been fully implemented optimally in accordance with its objectives, this was seen from the indicators (1) Communication (2) Resources (3) Disposition and (4) Bureaucratic structure. Inhibiting and Supporting Factors, which could occur at any stage Implementation of people's understanding was still lacking, the distance of the location of the remote companion so that it was less than optimal and the existence of social jealousy in the community
\end{abstract}

Keywords: Implementation, The Family Hope Program

\begin{abstract}
ABSTRAK
Penelitian ini bertujuan untuk Mengetahui Implementasi Program Keluarga Harapan (PKH) dan mengetahui faktor pendukung dan penghambat Program Keluarga Harapan (PKH) di Kabupaten Enrekang. Jenis penelitian yang akan digunakan didalam penelitian ini yaitu jenis penelitian kualitatif yang bersifat deskriptif yakni salah satu prosedur yang akan menghasilkan data deskriptif dalam bentuk kata-kata baik secara tertulis maupun secara lisan dari seseorang serta perilaku yang diamati. Teknik pengumpulan data yang digunakan adalah observasi, wawancara terhadap sejumlah informan. Hasil penelitian menunjukkan bahwa Implementasi Kebijakan Program Keluarga Harapan (PKH) di Kabupaten Enrekang belum sepenuhnya terlaksana dengan optimal sesuai dengan tujuannya, hal ini dilihat dari indikator (1) Komunikasi (Communication) (2) Sumber Daya (Resources) (3) Disposisi dan (4) Struktur birokrasi. Faktor Penghambat dan Pendukung, dimana dapat terjadi disetiap tahap Implementasi pemahaman masyarakat yang masih kurang, jarak tempuh lokasi pendamping jauh sehingga kurang maksimal dan adanya kecemburuan sosial di masyarakat.
\end{abstract}

Kata Kunci : Implementasi, Program Keluarga Harapan 
Kolaborasi : Jurnal Administrasi Publik, April 2020 Volume 6 Nomor 1

\section{PENDAHULUAN}

Upaya penanggulangan

kemiskinan telah dilakukan oleh Pemerintah, mulai dari penyediaan kebutuhan pangan, pelayanan kesehatan dan pendidikan, perluasan kesempatan kerja, pembangunan pertanian, pemberian dana bergulir dan pembangunan infrastruktur. Namun gejala kemiskinan di Indonesia belum sepenuhnya bisa teratasi.

Pemerintah Indonesia telah melaksanakan berbagai kebijakan dan program penanggulangan kemiskinan. Melalui Tim Nasional Percepatan Penangulangan Kemiskinan (TNP2K) di bawah koordinasi Wakil Presiden Republik Indonesia, Pemerintah mengklasifikasikan kebijakan dan program penanggulangan kemiskinan dalam tiga kelompok (klaster) kebijakan (Wrihatnolo, 2002: 77).

Dalam rangka penanggulangan kemiskinan berbasis rumah tangga, Pemerintah meluncurkan program khusus yang diberi nama Program Keluarga Harapan (PKH), yang dilaksanakan sejak tahun 2007. Meskipun pelaksanaan program ini seiring dengan berakhirnya program
Subsidi Langsung Tunai (SLT), tetapi bukan dimaksudkan sebagai kelanjutan program SLT. Program PKH lebih dimaksudkan sebagai upaya membangun sistem perlindungan kepada masyarakat miskin.

Program Keluarga Harapan $(\mathrm{PKH})$ merupakan program bantuan sosial yang bersyarat untuk keluarga dan/atau seseorang yang dinyatakan miskin dan rentan, terdaftar pada data terpadu program penanganan terhadap fakir miskin. Tujuan PKH ini adalah untuk meningkatkan taraf kehidupan keluarga sebagai penerima manfaat yang melalui akses pelayanan pendidikan, kesehatan, dan kesejahteraan sosial, serta juga mengurangi beban pengeluaran dalam meningkatkan pendapatan keluarga miskin. Payung hukum Program Keluarga Harapan (PKH) merupakan Peraturan Menteri Sosial Nomor 1 Tahun 2018 tentang Program Keluarga Harapan. Dalam rangka penanggulangan kemiskinan berbasis rumah tangga, Pemerintah meluncurkan program khusus yang diberi nama Program Keluarga Harapan (PKH), yang dilaksanakan sejak tahun 2007. Meskipun 
Kolaborasi : Jurnal Administrasi Publik, April 2020 Volume 6 Nomor 1

pelaksanaan program ini seiring dengan berakhirnya program Subsidi Langsung Tunai (SLT), tetapi bukan dimaksudkan sebagai kelanjutan program SLT. Program PKH lebih dimaksudkan sebagai upaya membangun sistem perlindungan kepada masyarakat miskin. Tahapan implementasi sebuah kebijakan merupakan tahapan yang krusial, karena tahapan ini menentukan keberhasilan sebuah kebijakan. Tahapan implementasi perlu dipersiapkan dengan baik pada tahap perumusan dan pembuatan kebijakan. Seperti yang di kemukakan oleh Suharno (2008: 187) "Implementasi kebijakan publik secara konvensional dilakukan oleh negaramelalui badan-badan pemerintah. Sebab implementasi kebijakan publik pada dasarnya merupakan upaya pemerintah untuk melaksanakan salah satu tugas pokoknya, yakni memberikan pelayanan publik (publik cervises). pada kenyataannya implementasi kebijakn publik yang beraneka ragam, baik dalam bidang, sasaran, dan bahkan kepentingan, memaksa pemerintah menggunakan kewenangan diskresi untuk menentukan apa yang harus dilakukan mereka dan apa yang mereka tidak lakukan".

Kabupaten Enrekang merupakan wilayah yang menerapkan sistem program keluarga harapan (PKH) Sebanyak 9.700 keluarga di Kabupaten Enrekang, bakal mendapat insentif dari bantuan Program Keluarga Harapan (PKH) tahun anggaran 2018. Bantuan senilai total Rp16 miliar ini, bakal disalurkan kepada kepala keluarga yang memiliki anggota keluarga yang masuk kategori ibu hamil, anak sekolah, lansia, jompo, cacat, sakit akut, dan dhuafa. Purwanto (2012: 13) menyatakan bahwa selama ini lebih banyak program atau kebijakan yang gagal dilaksanakan dari pada yang berhasil dilaksanakan, bahkan para ahli menyatakan bahwa implementasi yang berhasil hanyalah sebuah kebetulan (by chance), sementara kebijakan yang gagal dalam implementasi merupakan by design. Sehingga, perlambatan yang terjadi tersebut sangat mungkin disebabkan oleh banyaknya kendala dalam implementasi program penanggulangan kemiskinan. Dari penelitian yang telah dilakukan (Utomo, Hakim, \& Rubawanto, 
Kolaborasi : Jurnal Administrasi Publik, April 2020 Volume 6 Nomor 1

2010) mengenai pelaksanaan Program Keluarga Harapan (PKH) dalam meningkatkan kualitas hidup rakyat miskin di Kecamatan Purwoasri Kabupaten Kediri menyimpulkan bahwa target pelaksanaan PKH di Kecamatan Purwoasri yaitu terbantunya masyarakat tidak mampu khususnya Rumah Tangga Sangat Miskin (RTSM) di dalam memenuhi kebutuhan hidup berkaitan dengan pendidikan anaknya dan kesehatan ibu hamil dan balita. Hasil evaluasi membuktikan bahwa penerima PKH mau melakukan dan memenuhi komitmennya dikarenakan takut dengan adanya sanksi yang diberikan. Berdasarkan data yang ada diketahui bahwa setiap tahunnya peserta PKH mengalami penurunan. Terbukti dengan menurunnya jumlah peserta PKH dari 692 pada tahun 2009 dan menurun dari tahun ketahun sampai pada tahun 2013 ini dengan jumlah 528.

Menurut Nugroho (2006:23), ada dua karakteristik dari kebijakan publik, yaitu: 1) kebijakan publik merupakan sesuatu yang mudah untuk dipahami, karena maknanya adalah hal-hal yang dikerjakan untuk mencapai tujuan nasional; 2) kebijakan publik merupakan sesuatu yang mudah diukur, karena ukurannya jelas yakni sejauh mana kemajuan pencapaian cita-cita sudah ditempuh. Menurut Woll sebagaimana dikutip Tangkilisan (2003:2) menyebutkan bahwa kebijakan publik ialah sejumlah aktivitas pemerintah untuk memecahkan masalah di masyarakat, baik secara langsung maupun melalui berbagai lembaga yang mempengaruhi kehidupan masyarakat.

Menurut Edwards (1980:10) mendefinisikan kebijakan publik sebagai "suatu tindakan pemerintah yang berupa programprogram pemerintah untuk mencapai sasaran atau tujuan". Sedangkan menurut Dye dalam Howlett dan Ramesh (1981:2), kebijakan publik adalah segala yang dikerjakan pemerintah, mengapa mereka melakukan, dan perbedaan yang dihasilkannya (What government did, why they do it and what differences it makes).

Easton (2001:

mengemukakan bahwa cici-ciri khusus yang melekat pada kebijakan publik bersumber pada kenyataan bahwa kebijakan itu dirumuskan oleh orang orang yang memiliki 
Kolaborasi : Jurnal Administrasi Publik, April 2020 Volume 6 Nomor 1

wewenang dalam sisitem politik, yakni para tetua adat, para eksekutif, para legislator, para hakim, para administrator, dan sebagainya. Penjelasan Easton ini membawa implikasi terhadap kebijakan publik yang sekaligus merupakan ciri dari kebijakan publik .Suharno, (2008: 23-24) menjelaskan : (1) Kebijakan publik lebih merupakan tindakan yang lebih mengarah pada tujuan. (2) Kebijakan pada hakikatnya terdiri atas tindakan-tindakan yang saling berkaitan yang mengarah pada tujuan tertentu, yang dilakukan oleh pemerintah. (3) Kebijakan bersangkut paut dengan apa yang senyatanya dilakukan pemerintah. (4) Kebijakan publik mungkin berbentuk positif, mungkin pula negatif .

Yudistira, (2010) menjelaskan bahwa Implemntasi megacu pada tindakan untuk mencapai tujuan-tujuan yang telah ditetapkan dalam suatu keputusan. Tindakan ini berusaha untuk menggubah keputusan-keputusan tersebut menjadi pola-pola oprasional serta berusaha mencapai perubahanperubahan besar atau kecil sebagaiman yang telah diputuskan sebelumnya. Implementasi pada hakikatnya adalah uapaya pemahaman apa yang seharusnya terjadi setelah sebuah program dilaksanakan Proses implementasi kebijakan tidak hanya melibatkan instansi yang bertanggung jawab untuk pelaksanaan kebijakan tersebut, namun juga menyangkut jaringan kekuatan politik, ekonomi, dan soaial. Dalam tataran praktis, implementasi kebijkan adalah proses pelaksanaan keputusan dasar .

Menurut Willim N. Dunn dalam ( Subarsono, 2010: 14). ada berbagai kebijakan yang ditentang oleh masyarakat karena bersifat reaktif dan masih banyak kekurangan-kekurangan dan kelemahan dari kebijakan yang di keluarkan oleh pemerintah. Diantaranya kelemahan-kelemahan yang ada di dalam kebijakan adalah (1) inti permasalahan tidak dikenal, (2) mengalami kelemahan karena ditentang oleh masyarakat, autcomes kebijakan tidak seperti yang diharapkan.

Berbeda dengan Willim N. Dunn yang menyatakan bahwa sistem pemerintahan mencakup hubungan timbal balik, lain halnya dengan Edward yang lebih dikenal dengan Model Edward III (1980) 
Kolaborasi : Jurnal Administrasi Publik, April 2020 Volume 6 Nomor 1

mempertimbangkan empat faktor kritis atau variabel di dalam mengimplementasikan kebijakan publik, yaitu komunikasi, sumber daya, sikap atau disposisi, dan struktur birokrasi. Fakotr - faktor internal organisasi ini berpengaruh secara langsung terhadap implementasi, tetapi juga saling tergantung satu dengan yang lainnya. Edward menilai bahwa masalah utama administrasi publik adalah rendahnya perhatian terhadap implementasi. Secara tegas dikatakan bahwa" without effective implementation the decission of policymakes will not be carried out succesfully". Edward III melihat empat isu pokok (faktor penentu) yang perlu mendapat perhatian agar implementasi kebijakan menjadi efektif. Faktor-faktor yang berpengaruh dalam implentasi menurut Edward III sebagai berikut : (1) Komunikasi (Suratman, 2017) menjelaskan bahwa Implementasi akan berjalan efektif apabila ukuranukuran dan tujuan-tujuan kebijakan dipahami oleh individu-individu yang bertanggungjawab dalam pencapaian tujuan kebijakan. (2) Sumber Daya. Tanpa sumber daya yang memadai tentu implementasi kebijakan tidak akan berjalan secara optimal. (3) Disposisi/ Sikap. Salah satu faktor yang mempengaruhi efektifitas implementasi kebijakan adalah sikap implementor. Jika implemetor setuju dengan bagianbagian isi dari kebijakan maka mereka akan melaksanakan dengan senang hati tetapi jika pandangan mereka berbeda dengan pembuat kebijakan maka proses implementasi akan mengalami banyak masalah. (4) Struktur Birokrasi. Membahas badan pelaksana suatu kebijakan, tidak dapat dilepaskan dari struktur birokrasi. Struktur birokrasi adalah karakteristik, norma-norma, dan pola-pola hubungan yang terjadi berulang-ulang dalam badan-badan eksekutif yang mempunyai hubungan baik potensial maupun nyata dengan apa yang mereka miliki dalam menjalankan kebijakan.

Program di dalam Kamus Besar Bahasa Indonesia (KBBI) didefinisikan sebagai rancangan mengenai asas-asas serta usahausaha yang akan dijalankan. Jones dalam Arif Rohman (2009: 101-102) menyebutkan program merupakan salah satu komponen dalam suatu kebijakan. Program merupakan 
Kolaborasi : Jurnal Administrasi Publik, April 2020 Volume 6 Nomor 1

upaya yang berwenang untuk mencapai tujuan. Salah satu model implementasi program yakni model yang diungkapkan oleh David C. Korten (2005). Model ini memakai pendekatan proses pembelajaran dan lebih dikenal dengan model kesesuaian implementasi program.

Menurut Muhaimin (2009), bahwa Program merupakan pernyataan yang berisi kesimpulan dari beberapa harapan atau tujuan yang saling bergantung dan saling terkait, untuk mencapai suatu sasaran yang sama.Biasanya suatu program mencakup seluruh kegiatan yang berada di bawah unit administrasi yang sama, atau sasaran-sasaran yang saling bergantung dan saling melengkapi, yang semuanya harus dilaksanakan secara bersamaan atau berurutan.

\section{METODE PENELITIAN}

Penelitian ini menggunakan pendekatan kualitatif dengan tipe fenomenologi. Untuk kebutuhan pengumpulan data, Penelitian bertujuan untuk Mengetahui Implementasi Program Keluarga Harapan (PKH), faktor pendukung dan penghambat Program Keluarga Harapan (PKH) di Kabupaten
Enrekang .peneliti melakukan pengumpulan data primer yaitu data empiris yang diperoleh dari informan berdasarkan hasil wawancara. informan pada penelitian ini adalah Kepala Dinas Sosial di Kabupaten Enrekang ,Kepala Bidang Jaminan Sosial di Dinas Sosial Kabupaten Enrekang, Kordinator Pendamping $\mathrm{PKH}, \quad$ Pendamping $\mathrm{PKH}$, dan Penerima Bantuan PKH di Kabupaten Enrekang .

Data sekunder yang terdapat dalam penelitian ini yaitu data dikumpulkan peneliti dari berbagai laporan-laporan atau dokumendokumen bersifat informasi tertulis yang digunakan dalam penelitian terkait Implementasi Kebijakan Program Keluarga Harapan (PKH) di Kabupaten Enrekang. Dalam pengumpulan data yang digunakan teknik observasi, wawancara, dan dokumentasi dan dalam menganalisis data digunakan reduksi data, sajian data dan penarikan kesimpulan. Sedangkan untuk pengabsahan data digunakan tiga triangulasi yaitu triangulasi sumber, triangulasi waktu dan triangulasi teknik. 
Kolaborasi : Jurnal Administrasi Publik, April 2020 Volume 6 Nomor 1

HASIL DAN PEMBAHASAN

Dinas Sosial

Kependudukan Tenaga kerja dan

Transmigrasi Kabupaten Enrekang, sebagai Satuan Kerja Perangkat Daerah (SKPD) yang diberi mandat oleh Undang-undang sebagai penyelenggara kewenangan otonomi daerah dibidang Sosial Kependudukan Ketatanegaraan dan Transmigrasi selalu dituntut untuk meningkatkan kinerja organisasi agar tujuan pembangunan dapat dirumuskan dan dicapai secara efektif dan efisien.Kebijakan adalah suatu tindakan yang mengarah pada tujuan yang diusulkan oleh seseorang, kelompok atau pemerintah dalam lingkungan tertentu sehubungan dengan adanya hambatan-hambatan tertentu seraya mencari peluang-peluang untuk mencapai tujuan atau mewujudkan sasaran yang diinginkan, terutama dalam kaitan adanya peran fungsional Pemerintah di ranah publik sebagai pelayan masyarakat. Untuk menyelesaikan permasalahan yang berkembang di masyarakat diperlukan kebijakan sebagai realisasi dari fungsi dan tugas negara serta dalam rangka mencapai tujuan pembangunan. Dengan kata lain, kebijakan dibutuhkan untuk memecahkan masalah yang ada di ranah publik. Dan untuk itu dibutuhkan bukan hanya perumusan (rencana) program, tetapi juga implementasi program guna mencapai tujuan yang telah direncanakan. Suatu kebijakan harus diimplementasikan agar mempunyai dampak atas tujuan yang diinginkan. Tujuan PKH adalah membantu mengurangi kemiskinan dengan cara meningkatkan kualitas sumber daya manusia sebagai sumber daya manusia pada kelompok masyarakat sangat miskin.

PKH diharapkan dapat meningkatkan kualitas pelayanan kesejahteraan sosial yang bermartabat sehingga tercipta kemandirian lokal penyandang masalah kesejateraan sosial, dapat meningkatkan pendayagunaan sumber daya dan potensi aparatur untuk mampu memberikan pelayanan dibidang kesejahteraan sosial yang cepat, berkualitas dan memuaskan serta meningkatkan koordinasi dan partisipasi sosial masyarakat / stakehoders khususnya Lembaga Sosial masyarakat 
Kolaborasi : Jurnal Administrasi Publik, April 2020 Volume 6 Nomor 1

pemerhati di bidang kesejahteraan sosial masyarakat.

Untuk menjamin keberlangsungan suatu usaha atau kegiatan diperlukan dasar atau landasan hukum yang kuat, sehingga yang dimaksud dengan dasar program keluarga harapan di sini adalah landasan tempat berpijak atau bersandar dari dikembangkannya sebuah program tersebut . Adapun landasan hukum pelaksanaan program keluarga harapan berpedoman pada perundangundangan yang berlaku sebagai berikut,( Materi Diklat Pendamping PKH 2012): (a) Peraturan Presiden No. 15 tahun 2010 tentang percepatan penanggulanan kemiskinan. (b) Inpres No. 3 tahun 2010 tentang Program Pembangunan yang berkeadilan. (c) Keputusan Menteri Koordinator Bidang Kesejahteraan Rakyat selaku ketua Tim Koordinasi Penanggulangan Kemiskinan, No: 31/KEP/MENKO/-KESRA/IX/2007 tentang "Tim Pengendali Program Keluarga Harapan” tanggal 21 September 2007, (d) Keputusan Menteri Sosial Republik Indonesia No. 02A/HUK/2008 tentang “Tim Pelaksana Program Keluarga Harapan (PKH) Tahun 2008" tanggal
08 Januari 2008. (e) Keputusan Gubernur tentang "Tim Koordinasi Teknis Program Keluarga Harapan (PKH) Provinsi/TKPKD”.

Keputusan Bupati/Walikota tentang "Tim Koordinasi Teknis Program Keluarga Harapan (PKH) Kabupaten/Kota/TKPKD. (g) Surat Kesepakatan Bupati untuk Berpartisipasi dalam Program Keluarga Harapan . (h) Payung hukum Program Keluarga Harapan (PKH) adalah Peraturan Menteri Sosial Nomor 1 Tahun 2018 tentang Program Keluarga Harapan. Landasan hukum yang dipaparkan diatas merupakan acuan dalam melaksanakan Program Keluarga Harapan di Kota Enrekang. Program Keluarga Harapan (PKH) di bidang kesehatan mensyaratkan peserta PKH yaitu ibu hamil, ibu nifas, dan anak usia kurang dari enamtahun untuk melakukan kunjungan rutin ke berbagai sarana kesehatan. Oleh karena itu, program ini secara langsung akan mendukung pencapaian target program kesehatan. Adapun proses pelayanan kesehatan PKH antaralain : (A) Menghadiri pertemuan awal, Perwakilan puskesmas akan diundang untuk menghadiri acara 
Kolaborasi : Jurnal Administrasi Publik, April 2020 Volume 6 Nomor 1

pertemuan awal dengan seluruh calon peserta PKH. (B) Sosialisasi, Pemahaman program oleh semua pihak, baik yang terkait langsung maupun tidak langsung, merupakan kunci kesuksesan Program PKH. Untuk itu disusun strategi komunikasi dan sosialisasi PKH yang komprehensif dan melalui pendekatan multi pihak. Strategi komunikasi dan sosialisasi ini tidak hanya memfokuskan pada aspek implementasi dan keberhasilan pelaksanaan program $\mathrm{PKH}$, tetapi juga aspek pengembangan kebijakan, khususnya dalam membanguan dukungan dan komitmen untuk melembagakan $\mathrm{PKH}$ dalam bentuk Sistem Jaminan Sosial. (C) Memberi Pelayanan Kesehatan, Petugas kesehatan diharapkan mampu memberikan pelayanan kesehatan kepada semua peserta PKH. Dalam memberikan pelayanan, petugas kesehatan harus mengacu kepada ketentuan dan pedoman pelayanan kesehatan yang berlaku.

Pencairan dana PKH, Dalam pelaksanaannya Kantor Pos dapat membayarkan di lokasi-lokasi yang telah ditunjuk untuk lebih memudahkan warga penerima $\mathrm{PKH}$ untuk mencairkan dananya, khususnya warga di lokasi yang terpencil/jauh dari Kantor Pos. Penerima bantuan $\mathrm{PKH}$ adalah RTSM sesuai dengan kriteria BPS dan memenuhi satu atau beberapa kriteria program yaitu memiliki Ibu hamil/nifas, anak balita atau anak usia 5-7 tahun yang belum masuk pendidikan SD, anak usia SD dan SLTP dan anak 15-18 tahun yang belum menyelesaikan pendidikan dasar. Kartu tersebut digunakan untuk menerima bantuan PKH. Selanjutnya kartu PKH dapat berfungsi sebagai kartu Jamkesmas untuk seluruh keluarga penerima PKH tersebut sebagaimana yang dijelaskan dalam buku Pedoman Pelaksanaan Jamkesmas 2009. Penggunaan bantuan PKH ditujukan untuk meningkatkan kualitas pendidikan dan kesehatan, karenanya bantuan akan lebih efektif dan terarah, jika penerima bantuannya adalah ibu atau wanita dewasa yang mengurus anak pada rumah tangga yang bersangkutan. Dalam kartu peserta PKH yang tercantum adalah nama ibu/wanita yang mengurus anak, bukan kepala rumah tangga. Hal ini dikarenakan apabila dana bantuan program $\mathrm{PKH}$ diterima oleh kepala keluarga, maka bantuan 
Kolaborasi : Jurnal Administrasi Publik, April 2020 Volume 6 Nomor 1

tersebut dikhawatirkan tidak akan digunakan untuk kebutuhan anak akan tetapi bantuan tersebut dapat disalah gunakan untuk keperluan yang lain seperti contoh dibelikan rokok atau pun hal lainnya. Untuk itu, pada kartu kepesertaan PKH akan tercantum nama ibu/wanita yang mengurus anak, bukan kepala rumah tangga. Kepesertaan PKH tidak menutup keikutsertaan RTSM penerima pada program-program lainnya. Seperti Bantuan Operasional Sekolah (BOS), Asuransi Kesehatan Keluarga Miskin (ASKESKIN), Beras untuk Keluarga Miskin (RASKIN), dan sebagainya. Kewajiban penerima PKH adalah: 1) Berkaitan dengan kesehatan RTSM yang ditetapkan sebagai peserta $\mathrm{PKH}$ diwajibkan melakukan persyaratan berkaitan dengan kesehatan jika terdapat anggota keluarga terdiri dari anak 0-6 tahun dan/atau ibu hamil/nifas. Apabila terdapat anak usia 6 tahun yang telah masuk sekolah dasar, maka RTSM tersebut mengikuti persyaratan berkaitan dengan pendidikan. 2) RTSM ditetapkan sebagai peserta $\mathrm{PKH}$ diwajibkan melakukan persyaratan berkaitan dengan pendidikan jika terdapat anak yang berusia 6-15 tahun. Peserta PKH ini diwajibkan mendaftarkan anaknya ke SD/MI atau SMP/MTS (termasuk SMP/MTS terbuka) dan mengikuti kehadiran di kelas minimal 85 persen dari hari sekolah dalam sebulan selama tahun ajaran berlangsung. Program Keluarga Harapan adalah program yang memberikan bantuan tunai kepada RTSM. Sebagai imbalannya RTSM diwajibkan untuk memenuhi persyaratan yang terkait dengan upaya peningkatan kualitas sumber daya manusia (SDM), yaitu pendidikan dan kesehatan. Tujuan umum PKH untuk mengurangi angka kemiskinan dan memutus rantai kemiskinan, meningkatkan sumber daya manusia, serta merubah perilaku RTSM yang relatif kurang mendukung peningkatan kesejahteraan. Dalam Peraturan Menteri Kesehatan Nomor 40 Tahun 2012 Tentang Pedoman Pelaksanaan Program Jaminan Kesehatan Masyarakat mencantumkan bahwa seluruh peserta PKH merupakan penerima jasa kesehatan gratis yang disediakan oleh program Jamkesmas dan program lain yang diperuntukkan bagi orang tidak mampu. PKH memberikan bantuan tunai kepada rumah tangga sangat 
Kolaborasi : Jurnal Administrasi Publik, April 2020 Volume 6 Nomor 1

miskin (RTSM) dengan mematuhi ketentuan dan persyaratan yang ditetapkan. Penerima bantuan PKH diwajibkan melakukan sejumlah kewajiban aktifitas terkait dengan investasi jangka panjang pengembangan kualitas SDM. Misalnya, penggunaan layanan kesehatan dengan memanfaatkan layanan kesehatan pre-natal dan post-natal bagi ibu hamil, mengimunisasi anak, memantau tumbuh kembang anak. Di Dinas Sosial Kabupaten Enrekang, bentuk implementasi Program Keluarga Harapan(PKH) dari segi kesehatan , ditinjau dari beberapa aspek, anatara lain: (1) Komunikasi, (2) Sumber Daya, (3) Disposisi dan (4) Struktur Birokrasi . Adapun pembahasan secara rinci mengenai hal tersebut diuraikan sebagai berikut : (1) Komunikasi (Communication), Komunikasi diartikan sebagai proses penyampaian informasi komunikator kepada komunikan. Komunikasi dan sosialisasi PKH dirancang untuk terjadinya proses komunikasi,aliran informasi, dan pembelajran pada berbagai pelaksana di pusat dan di daerah, kalangan media, akademisi, dan masyarakat, termasuk peserta pkh, terutama di daerah PKH.
Komunikasi dalam organisasi merupakan suatu proses yang amat kompleks dan rumit.. Di samping itu sumber informasi yang berbeda akan melahirkan interpretasi yang berbeda pula. Tersosialisasikannya PKH kepada semua pihak, baik yang terikat langsung maupun yang tidak terikat, merupakan kunci kesuksekan PKH. Strategi komunikasi dan sosialisasi yang baik diperlukan untuk memberikan informasi kepada peserta PKH. implementasi Program Keluarga Harapan Di Kabupaten Enrekang dapat disimpulkan senada dengan hasil wawancara yang peneliti lakukan, bahwa komunikasi dan sosialisasi merupakan bentuk menyampaian informasi kepada para penerima bantuan $\mathrm{PKH}$, dikomunikasikan melalui telepon seluluer dan disosialisasikan tujuan $\mathrm{PKH}$, syarat-syarat, besaran bantuan, menjelaskan hak dan kewajiban peserta PKH. Hal tersebut sesuai dengan hasil observasi peneliti dilapangan yang menemukan bahwa hal yang disebutkan diatas sesuai dengan yang peneliti amati, dibuktikan dengan adanya daftar hadir sosialisasi PKH yang dilakukan oleh penyelenggara. (2) Sumber Daya (Resources), Dinas Sosial 
Kolaborasi : Jurnal Administrasi Publik, April 2020 Volume 6 Nomor 1

Kabupaten Enrekang , Program Keluarga Harapan (PKH) tidak terlepas dari adanya sumber daya, baik itu sumber daya manusia maupun sumber daya finansial. Dalam sebuah organisasi hal yang penting untuk melaksanakan semua kegiatan ataupun program di rancang oleh sumber daya manusia.Pada kegiatan ini, peneliti melakukan wawancara dengan bapak SR selaku Kordinator pendamping Program Keluarga Harapan(PKH) mengenai kualifikasi akademik staff pelaksanaan Program Keluarga Harapan (PKH) di Dinas Sosial Kabupaten Enrekang. Sumber daya yang ada, berupa Sumber daya manusianya, kualifikasi para pendamping, juga staff di Dinas Sosial Kabupaten Enrekang didominasi oleh S1, Diberikan pelatihan berupa FDS , pembimbingan yang terus menerus untuk membimbing KPM , penggunaan modul pendamping yang digunakan untuk pembimbingan kepada KPM . Dari dana finansialnya itu sendiri menggunakan dana sharing dari Kabupaten dan dana pelaksana dari pusat. (3) Disposisi, Disposisi atau sikap dari pelaksana kebijakan adalah faktor yang penting dalam pendekatan mengenai pelaksanaan atau kebijakan publik. Ada tiga bentuk sikap/respon implementor terhadap kebijakan ; kesadaran pelaksana, petunjuk/arahan pelaksana untuk merespon program kearah penerimaan atau penolakan, dan intensitas dari respon tersebut. Disamping itu dukungan para pejabat pelaksana sangat dibutuhkan dalam mencapai sasaran program . Implementasi kebijakan PKH di Dinas Sosial Kabupaten Enrekang dapat berhasil sesuai dengan apa yang diinginkan tentu tidak lepas dari sikap pelaksana, jika pelaksana memahami tentang apa yang akan di laksanakan dan memiliki kemampuan untuk melaksanakan, maka kebijakan tersebut bisa berjalan dengan baik sesuai ketentuanketentuan yang telah di tetapkan. Terlaksananya kebijakan yang efektif harus didukung oleh kemampuan dan kompetensi didalam pelaksanaan kebijakan yang dibuat oleh pemerintah. Pada kegiatan ini, peneliti melakukan wawancara dengan bapak YR selaku Kepala Dinas Sosial Kabupaten Enrekang mengenai bentuk sikap dan komitmen pendamping terhadap 
Kolaborasi : Jurnal Administrasi Publik, April 2020 Volume 6 Nomor 1

pelaksanaan Program Keluarga Harapan (PKH) di Dinas Sosial Kabupaten Enrekang.), dukungan para pejabat pelaksana sangat dibutuhkan dalam mencapai sasaran program . Namun ntuk sikap/ disposisi dari pendamping $\mathrm{PKH}$ masih sangat kurang, masih ada beberapa pendamping yang lalai akan tupoksinya dan kurang aktif dalam kegiatan sosialisasi yang dilakukan .Beberapa diantara dikarenakan tidak mendapat intensif sebagai bentuk penghargaanmaupun apresiasi dari pemerintah dan juga karena keterlambatan gaji, yang mengakibatkan mereka kurang bersemangat untuk bekerja.

Struktur birokrasi, Implementasi kebijakan di Dinas Sosial Kabupaten Enrekang yang bersifat kompleks menuntut adaya kerjasama banyak pihak. Ketika struktur birokrasi tidak kondusif terhadap implementasi suatu kebijakan, maka hal ini akan menyebabkan ketidakefektifan dan menghambat jalannya pelaksanaan kebijakan. Dinas Sosial Kabupaten Enrekang pun ini memiliki SOP (standar operasional procedure). Kebijakan yang komplek membutuhkan kerjasama banyak orang, serta pemborosan sumberdaya akan mempengaruhi hasil implementasi. Perubahan yang dilakukan tentunya akan mempengaruhi individu dan secara umum akan mempengaruhi sistem dalam birokrasi .Suratman, (2017). Tingkat pendapatan yang rendah dari RTSM berdampak tidak optimalnya dalam memenuhi kebutuhan pendidikan dan kesehatan. Pelaksanaan PKH dikabupaten Enrekang dari tahun 2016 belum sepenuhnya mampu mensejahterakan masyarakat miskin, dengan adanya PKH belum bisa mengubah kondisi sosial ekonomi RTSM, masyarakat masih memerlukan program-program pemerintah lainnya yang bisa meningkatkan penghasilan RTSM, namun dengan adanya PKH ini pemerintah memperbaiki kualitas anak-anak dari RTSM baik dari segi pendidikan maupun kesehatannya, sehingga diharapkan dalam jangka panjang anak-anak RTSM bisa meningkatkan status sosial ekonomi keluarganya dan upaya pemerintah untuk meningkatkan kesejahteraan masyarakat dapat dicapai. (5) Faktor Penghambat dan Pendukung. Faktor penghambat dalam suatu proses implementasi kebijakan merupakan suatu yang lazim terjadi dimana- 
Kolaborasi : Jurnal Administrasi Publik, April 2020 Volume 6 Nomor 1

mana, dan setiap program mempunyai masalah masing-masing , sehingga penanganannya pun biasanya dikembalikan kepada masing-masing aktor yang membuat suatu program dalam merespon masalah - masalah yang muncul dalam proses implementasi program. Program Keluarga harapan melalui pendamping program yang diberi mandat disetiap daerah, tentunya juga akan menemui kendala kendala dan faktor pendukung. faktor yang menjadi pendukung dalam implementasi program keluarga harapan ini adalah adanya berbagai pihak pemerintah yang ikut bekerjasama dalam mensosialisasikan dan menyukseskan terlaksananya Program Keluarga Harapan, dan yang menjadi faktor penghambat antara lain,pemahaman masyarakat yang masih kurang, jarak tempuh lokasi pendamping jauh sehingga kurang maksimal dan adanya kecemburuan sosial di masyarakat mengenai penerima bantuan PKH.

\section{KESIMPULAN}

Berdasarkan hasil penelitian dan pembahasan yang telah dilakukan mengenai Implementasi
Program Keluarga Harapan (PKH) di Kabupaten Enrekang sebagai berikut: (A) Di Dinas Sosial Kabupaten Enrekang , bentuk implementasi Program Keluarga Harapan(PKH) dari segi kesehatan, ditinjau dari beberapa aspek , anatara lain: (1) Komunikasi, dikomunikasikan melalui telepon seluluer dan disosialisasikan tujuan $\mathrm{PKH}$, syaratsyarat, besaran bantuan, menjelaskan hak dan kewajiban peserta PKH. (2) Sumber Daya, didominasi oleh S1, Diberikan pelatihan berupa FDS , pembimbingan yang terus menerus untuk membimbing KPM , penggunaan modul pendamping yang digunakan untuk pembimbingan kepada KPM . Dan untuk pemberian fasilitas diberikan motor dinas kepada para pendamping dan masih beberapa yang diusulkan. Dan dari dana finansialnya itu sendiri menggunakan dana sharing dari Kabupaten dan dana pelaksana dari pusat.(3) Disposisi, Sikap/ disposisi dari pendamping $\mathrm{PKH}$ masih sangat kurang, masih ada beberapa pendamping yang lalai akan tupoksinya dan kurang aktif dalam kegiatan sosialisasi yang dilakukan dan (4) Struktur Birokrasi Pembagian kerja di Dinas Sosial 
Kolaborasi : Jurnal Administrasi Publik, April 2020 Volume 6 Nomor 1

Kabupaten Enrekang jelas, karena masing-masing sudah dterbagi, dan semua telah mengetahui tupoksinya. Namun Koordinasi antara pemerintah pusat dan daerah belum berjalan dengan baik, masih diperlukan kerjasama pemerintah pusat maupun daerah untuk lebih memberikan dukungan terhadap pelaksanaan PKH. (2) Faktor Penghambat dan pendukung, Faktor yang menjadi pendukung dalam implementasi program keluarga harapan ini adalah adanya berbagai pihak pemerintah yang ikut bekerjasama dalam mensosialisasikan dan menyukseskan terlaksananya Program Keluarga Harapan, dan yang menjadi faktor penghambat antara lain,pemahaman masyarakat yang masih kura, jarak tempuh lokasi pendamping jauh sehingga kurang maksimal dan adanya kecemburuan sosial di masyarakat mengenai penerima bantuan PKH.

\section{DAFTAR PUSTAKA}

Arif Rohman.(2009). Memahami Pendidikan dan Ilmu Pendidikan. Yogyakarta: Laksbang Mediatama

Dye, Thomas R, 2005. Understanding Public Policy,
Elevent Edition, New Jersey: Pearson Prentice Hall

Dunn, William N., 2003. Pengantar Analisis Kebijakan Publik. Gadjah Mada University Press, Yogyakarta

Easton. 2001. Implementasi Program Keluarga Harapan (PKH) Di Desa Maron Kec. Kademangan Kab. Blitar : Jurnal Administrasi Negara FISIP UNESA

Edward III, dan George C. 1980. Implementing Public Policy, Congressional Quarterly Press, Washington.

Korten, David. 2005. Managemen Kinerja ektor Publik: Yogyakarta

Nugroho, Riant. 2006. Kebijakan Publik Formulasi, Implementasi dan Evaluasi. Jakarta:PT.Elek Media Komputindo.

Muhaimin, Suti'ah, dan Sugeng Listyo Prabowo, 2009, Manajemen Pendidikan, Jakarta: ...Kencana, h. 349.

Suharno. 2008. Program Keluarga Harapan (PKH) memotong matarantai kemiskinan anak bangsa. Pendidikan Pasca Sarjana Spesialis-1. Pekerja Sosial STKS Bandung

Suratman. 2017. Generasi Implementasi dan Evaluasi Kebijakan Publik. Surabaya: CAPIYA Publishing. 
Kolaborasi : Jurnal Administrasi Publik, April 2020 Volume 6 Nomor 1

Wrihatnolo, R.R. dan R.N.

Dwijowiyoto. 2007.

Manajemen Pemberdayaan.

Sehuah

Yudistira. 2010. Kebijakan Publik:

Teori dan Proses. Media

Presindo: Yogyakarta. 